\title{
RANCANG BANGUN GAME KUMBANG KUM OID MENGGUNAKAN ALGORITMA A* (STAR) BERBASIS ANDROID
}

\author{
Dede Sunarto $^{1}$, Rio Andriyat Krisdiawan ${ }^{2}$ \\ Program Studi Teknik Informatika, Fakultas Ilmu Komputer, Universitas Kuningan \\ Kampus I : Jalan Cut Nyak Dhien Kelurahan Cijoho Kuningan (0232) 875097 \\ dede.sunarto92@gmail.com,rioandriyat@uniku.ac.id
}

\begin{abstract}
Abstrak - Game merupakan salah satu media hiburan yang sangat populer untuk semua orang. Teknologi game telah mengalami kemajuan yang sangat pesat. Salah satunya adalah game Kumbang Kum Oid yang memberi tantangan dalam setiap permainan. Game juga bisa diartikan sebagai arena kepuasan dan aksi permainan. Permainan berbasis Android yang mana hanya bisa dimainkan di handphone Android, dirancang dengan menerapkan Artificial intelligence (AI). Algoritma yang digunakan dalam game Kumbang Kum Oid ini adalah Algoritma A* (Star). Dimana Algoritma A* (Star) merupakan perbaikan dari BFS dengan memodifikasi fungsi heuristicnya yang akan meminimumkan total cost lintasan. Sehingga Algoritma A* (Star) akan memberikan solusi terbaik dalam waktu yang optimal. Dari hasil pengujian yang dilakukan game Kumbang Kum Oid mampu menemukann jalur dengan rute terpendek. Pencarian jalur akan berhasil menemukan solusi berupa rute terpendek, jika terdapat jalur yang bisa dilalui (ada jalur yang tidak tertutup dinding labirin) dan akan gagal dalam menemukan solusi jika tidak ada jalur yang bisa dilalui atau semua jalur yang ada tertutup oleh dinding labirin.
\end{abstract}

Kata Kunci $\quad$ : Game, Android, Algoritma A*(Star), Artificial intelligence.

Abstract - Game is one of entertainment media which is very popular for everyone. Game technology has progressed very rapidly. One of them is the game Kumbang Kum Oid which gives challenge in every game. Game can also be interpreted as an arena of satisfaction and action games. Android-based games which can only be played on Android phones, designed by applying Artificial intelligence (AI). The algorithm used in this Kum Oid Beetle game is the A* (Star) Algorithm. Where A * (Star) Algorithm is an improvement of BFS by modifying its heuristic function which will minimize the total running cost. So the A* (Star) Algorithm will provide the best solution in the optimal time. From the test results conducted game Kumbang Kum Oid able to find the path with the shortest route. The path search will succeed in finding the solution of the shortest route, if there is a path that can be passed (there is a path that is not closed the labyrinth wall) and will fail to find a solution if there is no path that can be passed or all the paths are covered by the labyrinth wall.

Keywords: Game, Android, Algorithm A * (Star), Artificial intelligence

\section{PENDAHULUAN}

\subsection{Latar Belakang}

Perkembangan dunia komputer dan dunia game diera globalisasi tidak dapat dipisahkan. Dunia teknologi mengalami perkembangan yang sangat pesat begitu juga dengan game yang saat ini sangatlah cepat bekembang seiring semakin banyaknya peminat game serta didukungnya sarana dan prasarana untuk bermain dan membuat game.

Game merupakan satu media hiburan yang sudah menjadi trend pada saat ini, game tidak hanya dijadikan sebagai media hiburan 
semata, bahkan sebagian dibuat dengan tujuan sebagai media pembelajaran dengan keefektifan yang tinggi. Game dapat membantu melatih seseorang yang memiliki masalah dalam konsentrasi, dengan demikian game dibuat sebagai media hiburan sekaligus media pembelajaran yang efektif dalam proses penyerapan dan dapat melatih seorang dalam konsentrasi.

Game Kumbang Kum Oid adalah sebuah permainan yang sudah tidak asing yang merupakan gambaran sebuah permainan dengan jaringan jalan yang rumit dan berliku, tujuan pemainan ini adalah pemain harus mencari jalan keluar menuju sebuah tujuan yang dinyatakan sebagai garis akhir permainan dan dimana dalam perjalanan banyak mendapat rintangan untuk sampai tujuan.

Hasil penelitian Agung Pamungkas (2014). Permainan Labirin atau maze adalah sebuah puzzle yang memiliki bentuk percabangan jalan yang kompleks dan memiliki banyak jalan buntu. Selama ini memang telah banyak beredar game Labirin, namun permainan yang ada tersebut hanya sebatas hiburan semata serta jarang menerapkan algoritma dalam penyelesaiannya. Alasan inilah yang membuat penulis ingin mencoba untuk menerapkan algoritma A* (A Star) pada game edukasi The Maze Island berbasis Android.

Penelitian tentang game dengan menerapkan algoritma A* (Star) pada Game Kumbang Kum Oid berbasis Android menyatakan Game Kumbang Kum Oid ini termasuk dalam Game Labirin dimana pemain diharuskan untuk mencari jalan keluar dengan rute terpendek. Algoritma A* (Star) memberikan solusi terbaik untuk memecahkan masalah ini. Tujuan utama dari permainan ini adalah untuk menerapkan algoritma A* (Star) dalam memberikan hasil pencarian untuk menemukan pintu keluar dengan rute terpendek.

Target penulis membuat game ini adalah untuk kalangan semua umur, mulai dari anak-anak sampai dewasa. Hal ini pula yang menjadi latar belakang penulis melakukan penelitian yang penulis sajikan dalam skripsi ini yang berjudul

$\begin{array}{lcr}\text { "Rancang } & \text { Bangun } & \text { Game } \\ \text { Kumbang } & \text { Kum } & \text { Oid } \\ \text { Menggunakan } & \text { Algoritma } & \text { A* } \\ \text { (Star) Berbasis Android". } & \end{array}$

\subsection{Identifikasi Masalah}

Berdasarkan uraian pada latar belakang di atas, masalah dapat di identifikasi sebagai berikut :

1. Belum adanya sebuah Game Kumbang Kum Oid yang dilengkapi dengan karakter musuh untuk membuat game menjadi lebih menantang.

2. Belum adanya pencarian rute terpendek dalam game yang sejenis.

\subsection{Batasan Masalah}

Untuk menghindari pembahasan yang meluas, maka penulis hanya membatasi permasalahan sebagai berikut :

1. Game Kumbang Kum Oid ini hanya dapat dimainkan oleh single player.

2. Game Kumbang Kum Oid ini memiliki 3 tingkat kesulitan diantaranya sebagai berikut: waktu yang ditentukan 60 detik.
a) Level mudah 3 map dengan
b) Level sedang 3 map dengan waktu yang ditentukan 50 detik.
c) Level sulit 3 map dengan waktu yang ditentukan 40 detik.


3. Rancang game Kumbang Kum Oid ini dibuat menggunakan bahasa pemrograman berbasis android dan software yang di gunakan sebagai berikut :

a) JDK (Java Development Kit).

b) Android SDK (Software Development Kit).

c) Eclipse sebagai IDE (Interface Development Kit).

4. Game Kumbang Kum Oid ini dalam pengoperasian player menggunakan digital analog.

5. Pada karakter musuh dalam game Kumbang Kum Oid menerapkan algoritma A* (Star).

\subsection{Tujuan Penelitian}

Tujuan dari penelitian ini adalah sebagai berikut :

1. Untuk membangun game Kumbang Kum Oid berbasis android.

2. Untuk menemukan jalur terpendek pada karakter musuh yang dapat dilalui dari start node menuju goal node dengan memakai algoritma A* (Star).

3. Untuk menciptakan game yang menarik yang dapat meningkatkan saraf motorik.

\subsection{Manfaat Penelitian}

Manfaat bagi penulis antara lain :

1. Melatih mahasiswa dalam menerapkan dan mengembangkan ilmu serta teori-teori yang telah didapatkan selama kuliah.

2. Memahami penerapan algoritma A* (Star) untuk membangun suatu aplikasi game Kumbang Kum Oid serta mencari lintasan tercepat.

3. Dapat meningkatkan kualitas sebuah game Kumbang Kum Oid dengan menambahkan karakter musuh pada game.

Manfaat bagi pengguna antara lain :
1. Melatih daya ingat melalui permainan.

2. Melatih konsentrasi antara otak kanan dan otak kiri.

3. Melatih kesabaran dalam menyelesaikan suatu kasus dimana mencari jalur keluar.

\subsection{Metodologi Penelitian}

Metode penelitian yang penulis gunakan yaitu sebagai berikut :

\subsubsection{Teknik Pengumpulan Data}

Adapun teknik pengumpulan ini adalah Studi literatur yaitu mencari dan mengumpulkan literatur-literatur ilmiah yang diambil selain dari buku-buku yang ada. Serta mencari dari internet ataupun melalui perkumpulan surat-surat elektronik yang terkait dengan permasalahan yang dihadapi dalam penyusunan penelitian.

\subsubsection{Metode Pengembangan Sistem}

Metode penyelesaian masalah yang digunakan dalam penelitian ini adalah menggunakan metode RUP (Rational Unified Process).

RUP (Rational Unified

Process) adalah pendekatan pengembangan perangkat lunak yang dilakukan berulang-ulang (iterative), fokus pada arsitektur (architecture-centric), lebih diarahkan berdasarkan penggunaan kasus (use case driven) (Rosa AS, M. Shalahuddin: 2015).

RUP merupakan proses rekayasa perangkat lunak dengan pendefinisian yang baik (well defined) dan penstrukturan yang baik (well structured). RUP menyediakan pendefinisan struktur yang baik untuk alur hidup proyek perangkat lunak. RUP adalah sebuah produk proses perangkat lunak yang dikembangkan oleh Rational 
Software yang diakuisisi oleh IBM di bulan Februari 2003.

RUP memiliki empat buah tahap atau fase yang dapat dilakukan pula secara iteratif. Berikut ini adalah gambar 1.1. alur hidup RUP :

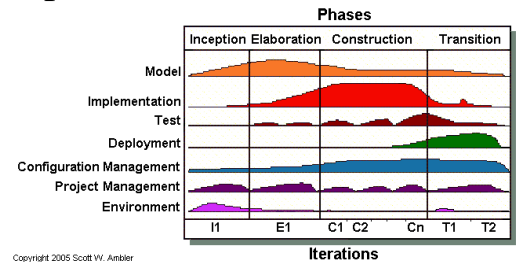

Gambar 1.1. Gambar Fase RUP

(Rational Unified Process)

(AS, Rosa dan Shalahuddin, M : 2015)

Pada Gambar 1.1. merupakan alur hidup RUP yang diawali dengan Fase Inception, Elaboration, Construction, dan diakhiri dengan fase Transition.

Berikut ini penjelasan untuk setiap fase RUP

1. Inception (permulaan)

Tahap ini lebih pada memodelkan proses bisnis yang dibutuhkan (business modeling) dan mendefinisikan kebutuhan akan sistem yang akan dibuat (requirements).

Berikut adalah tahapan yang di butuhkan pada tahap ini:

a) Memahami ruang lingkup dari proyek (termasuk pada biaya, waktu, kebutuhan, resiko dan lain sebagainya).

b) Membangun kasus bisnis yang dibutuhkan.

\section{Elaboration}

(perluasan/perencanaan)

Tahap ini lebih difokuskan pada perencanaan arsitektur sistem. Tahap ini juga dapat mendeteksi apakah arsitektur sistem yang diinginkan dapat dibuat atau tidak. Mendeteksi resiko yang mungkin terjadi dari arsitektur yang dibuat. Tahap ini lebih pada analisis dan desain sistem serta implementasi sistem yang focus pada purwarupa sistem (prototype).

Pada tahap ini saya menganalisa masalah yang ada dan membuat konsep pemecahan masalah. Perancangan menggunakan UML.

3. Construction (konstruksi)

Tahap ini fokus pada pengembangan komponen dan fitur-fitur sistem. Pada tahap ini saya melakukan sederatan iterasi kemudian membuat perancangan aplikasi, coding program, testing beta performance, bahasa pemprograman java, dan pengujian dengan black box dan white box.

4. Transition (transisi)

Tahap ini lebih pada deployment atau instalasi sistem agar dapat dimengerti oleh user. Aktifitas pada tahap ini termasuk pada pelatihan user, pemeliharaan dan pengujian sistem apakah sudah memenuhi harapan user. Pada tahap ini saya membuat apa yang sudah dimodelkan menjadi suatu produk jadi.

Produk perangkat lunak juga disesuaikan dengan kebutuhan yang didefinisikan pada tahap inception. Jika semua kriteria objektif terpenuhi maka dianggap sudah memenuhi Product Release Milestone (batas/tonggak peluncuran produk) dan pengembangan perangkat lunak selesai dilakukan.

Akhir dari keempat fase ini adalah produk perangkat lunak yang sudah lengkap. Keempat fase pada RUP akan 
dijalankan secara berurutan dan iteratif dimana setiap iterasi dapat digunakan untuk memperbaiki iterasi berikutnya.

\section{LANDASAN TEORI}

\subsection{Rancang Bangun}

Rancang merupakan serangkaian prosedur untuk menerjemahkan hasil analisis dari sebuah sistem kedalam bahasa pemrograman untuk mendeskripsikan dengan detail bagaimana komponen-komponen sistem diimplementasikan. Sedangkan pengertian bangun atau pembangunan sistem adalah kegiatan menciptakan baru maupun mengganti atau memperbaiki sistem yang telah ada baik secara keseluruhan maupun sebagian. (Pressman Ph.D dan Roger,S : 2002).

Rancang bangun sangat berkaitan dengan perancangan sistem yang merupakan satu kesatuan untuk merancang dan membangun sebuah aplikasi. Menurut (Sutabri, T : 2005) : 284) perancangan sistem adalah penentuan proses dan data yang diperlukan oleh sistem baru. Jika sistem itu berbasis komputer, rancangan dapat menyertakan spesifikasi jenis peralatan yang akan digunakan. Sedangkan (Jogiyanto, H,M : 2001) : 196) menjelaskan bahwa perancangan sistem dapat didefinisikan sebagai gambaran, perencanaan, dan pembuatan sketsa atau pengaturan dari beberapa elemen yang terpisahkan kedalam satu kesatuan yang utuh dan berfungsi. Tujuan dari perancangan sistem yaitu untuk memenuhi kebutuhan para pemakai sistem dan memberikan gambaran yang jelas dan rancang bangun yang lengkap kepada programer. Kedua tujuan ini lebih berfokus pada perancangan atau desain sistem yang terinci yaitu pembuatan rancang bangun yang jelas dan lengkap yang nantinya digunakan untuk pembuatan program komputernya.

Dari penjelasan diatas dapat disimpulkan rancang bangun sistem merupakan kegiatan menterjemahkan hasil analisa kedalam bentuk paket perangkat lunak kemudian menciptakan sistem tersebut atau memperbaiki sistem yang ada.

\subsection{Game}

\subsubsection{Pengertian Game}

Game atau permainan adalah sesuatu yang dapat dimainkan dengan aturan tertentu sehingga ada yang menang dan ada yang kalah, Bermain game sudah dapat dikatakan sebagai life style masyarakat dimasa kini. Dimulai dari usia anak - anak hingga orang dewasa pun menyukai video game. Itu semua dikarenakan bermain video game adalah hal yang menyenangkan. (Anggara : 2008).

\subsubsection{Jenis - Jenis Game}

Ada beberapa jenis program permainan (Henry, S : 2005), yaitu:

\section{Maze Game}

Jenis game ini adalah jenis game yang paling awal muncul. Contoh game yang paling populer adalah game Pacman, sebagian mungkin pernah memainkan game ini. Secara sederhana game ini hanya mengitari maze (lorong-lorong yang berhubungan) dan memakan beberapa item untuk menambah tenaga atau kekebalan. Dalam game ini tentunya ada musuh yang mengejar pemain dan bila pemain mendapatkan kekebalan dapat berbalik mengejar musuh. 
2.3. Algoritma $\mathbf{A}^{*}$ (Star)

Algoritma A* (Star) adalah algoritma yang dikemukakan oleh Hart, Nilsson, dan Raphael pada tahun 1968. Algoritma A* (Star) merupakan salah satu algoritma Branch \& Bound atau disebut juga sebagai sebuah algoritma untuk melakukan pencarian solusi dengan menggunakan informasi tambahan (heuristik) dalam menghasikan solusi yang optimal.

$$
F(n)=G(n)+H(n)
$$

Dimana :

$$
\begin{aligned}
& \mathrm{F}(\mathrm{n}) \quad=\text { ongkos untuk simpul } \mathrm{n} \\
& \mathrm{G}(\mathrm{n})=\text { ongkos mencapai simpul } \mathrm{n} \\
& \text { dari akar } \\
& \mathrm{H}(\mathrm{n}) \begin{array}{l}
\text { = ongkos mencapai simpul } \\
\text { tujuan dari simpul } \mathrm{n}
\end{array}
\end{aligned}
$$

Berikut adalah flowchart system pengimplementasian Algoritma A* (Star) :

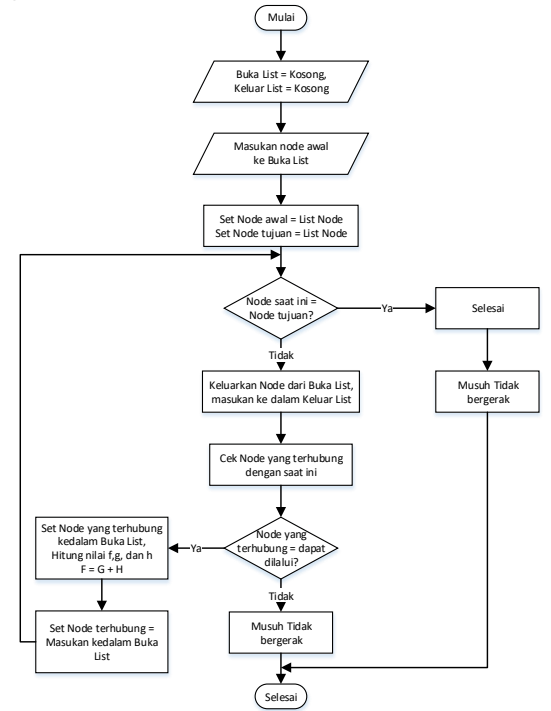

Gambar 2.1. Flowchart Algoritma A* (Star) pada Game Kumbang Kum Oid

Untuk tahapan atau alur dari sistem algoritma A* (Star) yaitu sebagai berikut :

1. Menentukan nilai Buka List dan Keluar List dengan nilai null atau kosong dan masukkan node awal ke Buka List.
2. Jila node awal (current node) merupakan kondisi node tujuan (goal state) maka proses Algoritma A* (Star) selesai, namun jika masih tidak ditemukan goal state maka best node dari Buka List akan dimasukkan kedalam Keluar List agar tidak dipilih kembali kondisi urutan tersebut sehingga Pengulangan (looping) tidak terjadi secara terus menerus.

3. Karena best node sudah dimasukkan kedalam Keluar List maka proses berlanjut mencari kembali best node yang ada didalam Buka List dengan menghitung fungsi $\mathrm{g}(\mathrm{n})$ dan $\mathrm{h}(\mathrm{n})$ proses ini dilakukan hingga node yang bertetanggaan langsung dengan node kosong telah dihitung semua nilai $\mathrm{f}(\mathrm{n})$ nya dan didapatkan nilai yang paling kecil dari kondisi saat ini.

4. Masukkan nilai terkecil tersebut kedalam best node Buka List dan ulangi langkah 2 hingga didapat jalur terbaik.

\subsection{Android}

Andorid merupakan sistem operasi untuk perangkat lunak mobile yang berbasis Linux dan bersifat terbuka atau open source dengan lisensi GNU yang dimiliki Google.

Sekitar bulan September 2007 sebuah studi melaporakan bahwa Google mengajukan hak paten aplikasi telepon seluler yang akhirnya dinamakan Nexus One, salah satu jenis telepon pintar GSM yang menggunakan Android pada sistem operasinya. Telepon seluler ini diproduksi oleh HTC Corporation dan tersedia di pasaran pada tanggal 5 Januari 2010. Kemudian pada tanggal 9 Desember 2008, diumumkan 
anggota baru yang bergabung dalam program kerja Android ARM Holdings, Atheros Communications, diproduksi oleh Asustek Computer Inc, Garmin Ltd, Softbank, Sony Ericsson, Toshiba Corp, dan Vodafaone Group Plc.

Berikut ini beberapa versi Android, yaitu :

\subsubsection{Android versi 4.1 (Jelly Bean)}

Android 4.1 Jelly Bean secara resmi diluncurkan pada bulan Juli 2012. Tidak ada update besar pada versi kali ini selain peningkatan pada performanya. Tampilan antar muka pada Android OS ini menjadi lebih halus dibandingkan Android ICS. Android 4.1 Jelly Bean juga menjadikan browser Google Chrome sebagai browser utama dan juga tentunya menghadirkan aplikasi yang sangat fenomenal yaitu Google Now.

Android Jelly Bean membawa sejumlah keunggulan dan fitur baru. Penambahan widget pada lock screen, Quick Settings, Bluetooth Low Energy support, OpenGL 3.0, dukungan resolusi $4 \mathrm{~K}$, dan juga beberapa peningkatan input keyboard, desain baru fitur pencarian, UI yang baru dan pencarian melalui Voich Search yang lebih cepat.

\section{ANALISIS DAN PERANCANGAN SISTEM}

\subsection{Perancangan Sistem}

Perancangan adalah langkah pertama dalam fase pengembangan rekayasa produk atau sistem. Perancangan itu adalah proses penerapan berbagai teknik dan prinsip yang bertujuan untuk mendefinisikan sebuah peralatan, satu proses atau satu sistem secara detail yang membolehkan dilakukan realisasi fisik (Pressman, Ph.D dan Roger, S : 2010).

Perancangan sistem disini akan terbagi menjadi beberapa tahap perancangan yaitu perancangan flowchart algoritma yang digunakan dalam pembuatan game Kumbang Kum Oid ini, perancangan use case diagram, perancangan activity diagram, perancangan sequence diagram, perancangan class diagram dan perancangan tampilan antarmuka aplikasi.

\section{Use Case Diagram}

Use case diagram ini akan mengggambarkan fungsi yang dapat dilakukan oleh sistem di Game Kumbang Kum Oid antara pengguna (Aktor) dengan sistem informasi yang ada. Seperti pada gambar 3.2 tentang use case diagram sistem aplikasi game Kumbang Kum Oid.

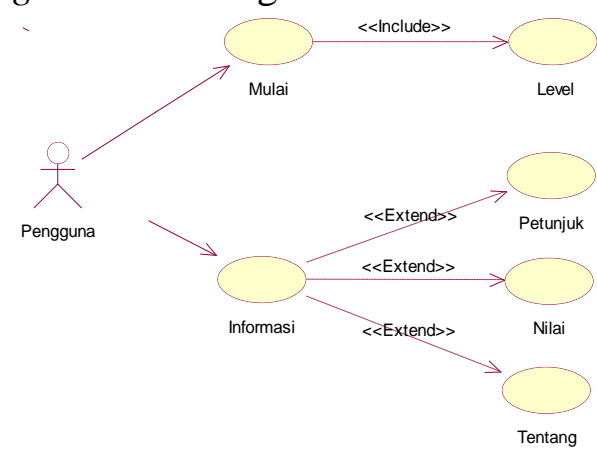

Gambar 3.1. Use Case Diagram System

\section{Activity Diagram}

Activity Diagram akan menampilkan aliran kerja atau aktivitas dari sebuah sistem yang ada pada aplikasi game Kumbang Kum Oid. Di mana aktivitas ini akan menggambarkan aktivitas sistem dan bukan yang dilakukan oleh aktor terhadap aplikasi, jadi activity diagram ini akan menampilkan aktivitas-aktivitas yang dilakukan oleh system. 


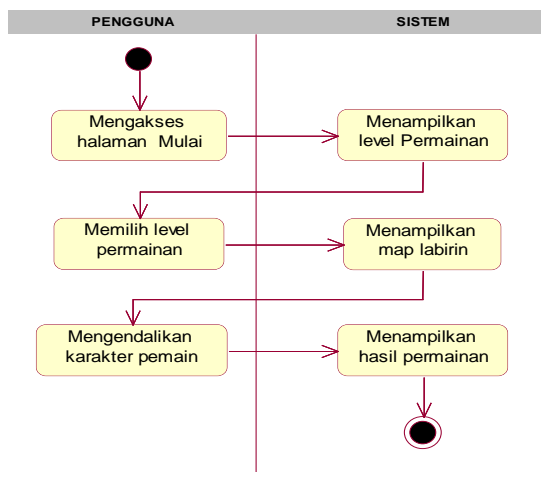

Gambar 3.2. Activity Diagram Mulai

B. Activity Diagram Level Permainan

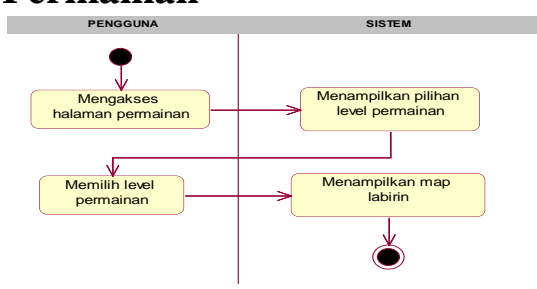

Gambar 3.3. Activity Diagram Level Permainan

\section{Activity}

Diagram

\section{Informasi}

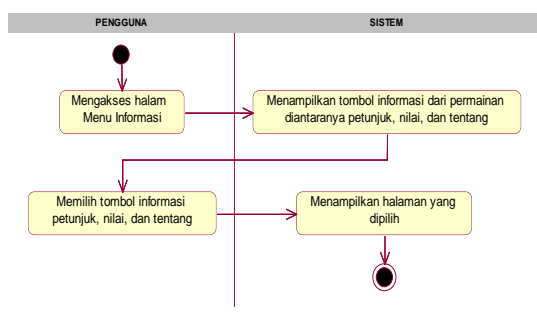

Gambar 3.4. Activity Diagram Informasi

\section{Activity Diagram Petunjuk}

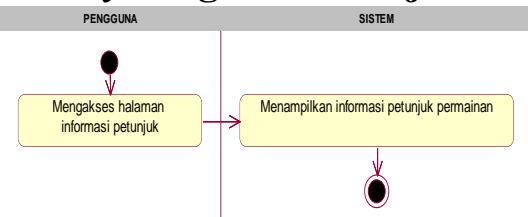

Gambar 3.5. Activity

Diagram Petunjuk

E. Activity Diagram Nilai

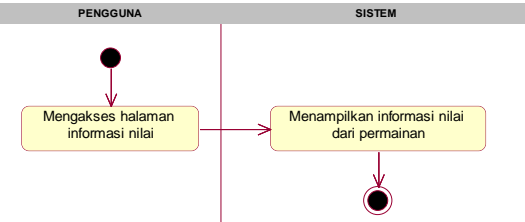

Gambar 3.6. Activity

Diagram Nilai

F. Activity Diagram Tentang

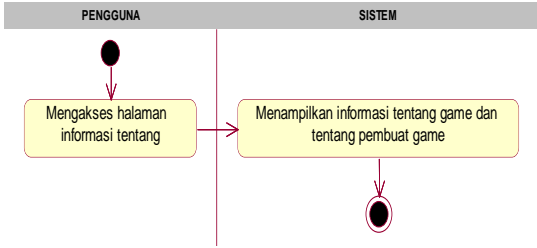

Gambar 3.7. Activity Diagram Tentang

\section{Sequence Diagram}

Sequence Diagram akan menggambarkan kelakuan objek pada use case dengan mendefinisikan waktu hidup objek dan pesan yang dikirim dan diterima antar objek. Banyaknya sequence diagram yang dapat digambarkan minimalnya sebanyak pendefinisian use case yang telah didefinisikan interaksi jalannya pesan sudah mencangkup pada sequence diagram sehingga semakin banyak use case yang didefinisikan maka sequence diagram yang harus dibuat juga semakin banyak.

Berikut adalah penggambaran sequence diagram untuk use case mulai, use case pentunjuk, use case pengaturan, use case level, use case nilai dan use case tentang.

A. Sequence Diagram Mulai

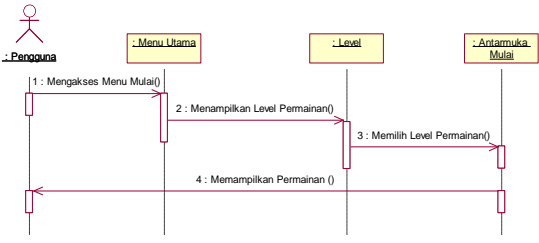

Gambar 3.8. Sequence

Diagram Mulai

B. Sequence Diagram Level Permainan

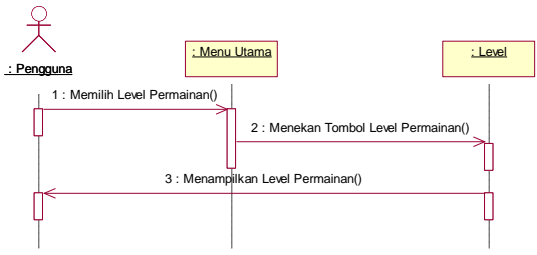

Gambar 3.9. Sequence

Diagram Level Permainan 
C. Sequence Diagram Informasi

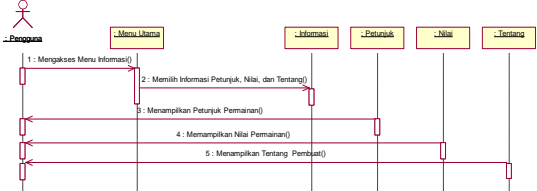

Gambar 3.10. Sequence Diagram Informasi

D. Sequence Petunjuk

Diagram

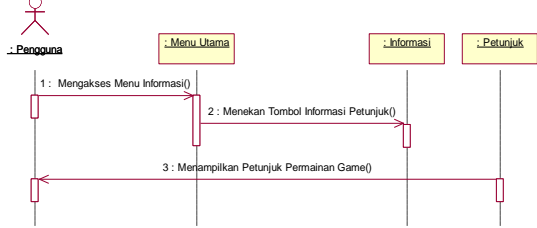

Gambar 3.11. Sequence

Diagram Petunjuk

\section{E. Sequence Diagram Nilai}

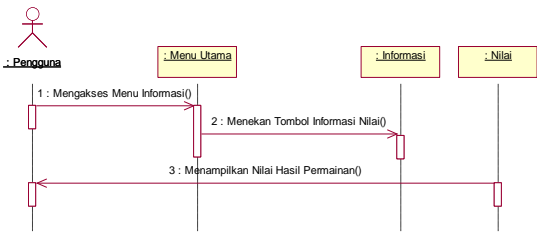

Gambar 3.12. Sequence Diagram Nilai

F. Sequence Tentang

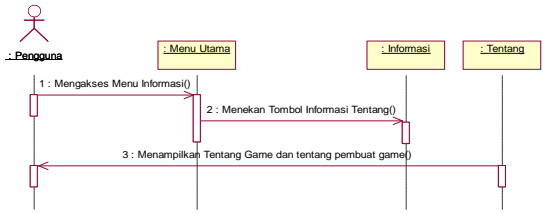

Gambar 3.13. Sequence

Diagram Tentang

\section{Class Diagram}

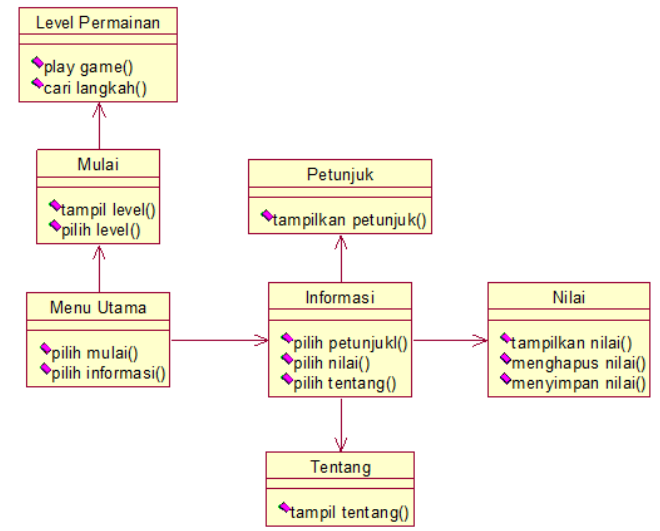

Gambar 3.14. Class Diagram game Kumbang Kum Oid
4.IMPLEMENTASI

DAN

\section{PEMBAHASAN SISTEM}

\subsection{Implementasi Sistem}

Implementasi perancangan pada aplikasi game Kumbang Kum Oid dilakukan dengan menggunakan bahasa pemrograman java android, program tersebut dijalankan pada system operasi mobile android hasil dari implementasi perancangan ini adalah melakukan pencarian lintasan terpendek yang dilakukan oleh karakter musuh dengan menggunakan Algoritma A* (Star).

\subsection{Desain Antarmuka (Interface)}

Desain antarmuka adalah tampilan yang terdapat pada aplikasi yang telah dibangun dan dijalankan dalam smartphone.

1. Desain Antarmuka Awal Game

Pada halaman utama ini menampilkan Splash Screen game Kumbang Kum Oid yang menuju halaman Menu Game, seperti pada gambar 4.1. berikut :

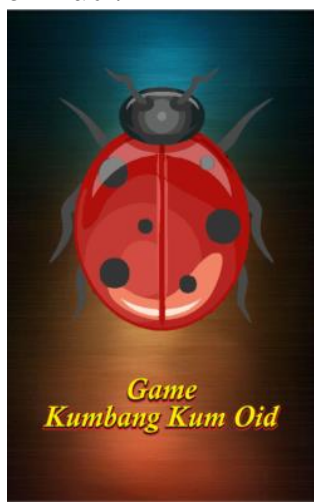

Gambar 4.1. Desain

Antarmuka Awal Game

2. Desain Antarmuka Menu

Pada halaman Menu ini menampilkan button yang menuju halaman-halaman tertentu, seperti pada gambar 4.2. berikut : 


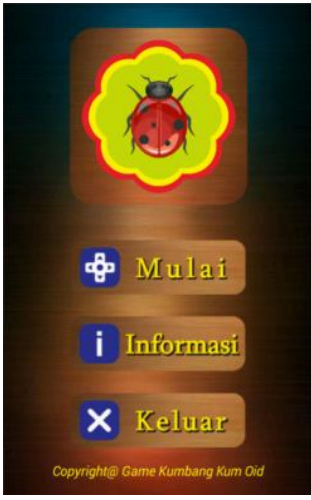

Gambar 4.2. Desain

Antarmuka Menu

\section{Desain Antarmuka Level Permainan}

Pada halaman level ini pengguna akan dihadapkan 3 buah button yang terbagi atas button mudah, button sedang dan button sulit, masingmasing level 3 button seperti pada gambar 4.3.

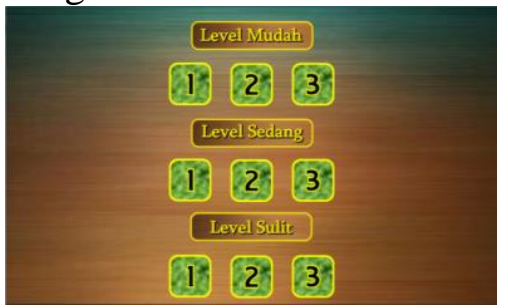

Gambar 4.3. Desain

Antarmuka Level Permainan

4. Desain Antarmuka Mulai Permainan

Pada halaman permainan ini menampilkan map game Kumbang Kum Oid sesuai level yang dipilih, waktu permainan, karakter pemain dan karakter musuh, seperti pada gambar berikut :

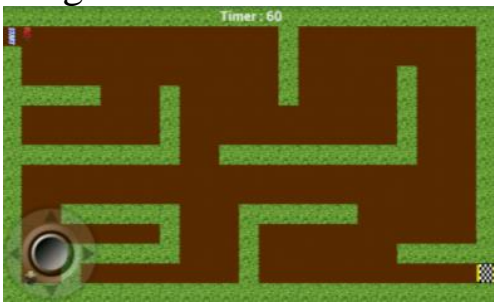

Gambar 4.4. Antarmuka halaman permainan level mudah1

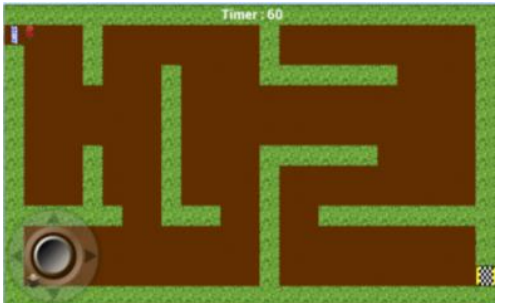

Gambar 4.5. Antarmuka halaman permainan level mudah2

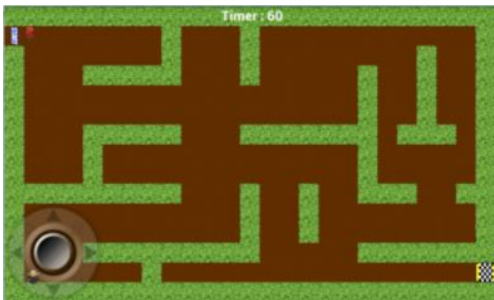

Gambar 4.6. Antarmuka halaman permainan level mudah3

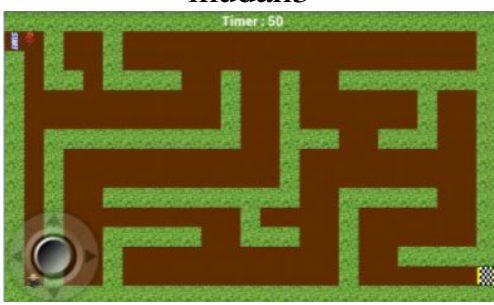

Gambar 4.7. Antarmuka halaman permainan level sedang 1

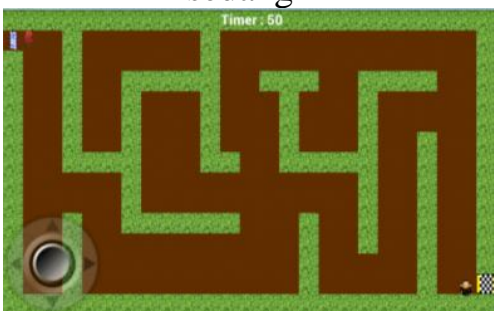

Gambar 4.8. Antarmuka halaman permainan level sedang2

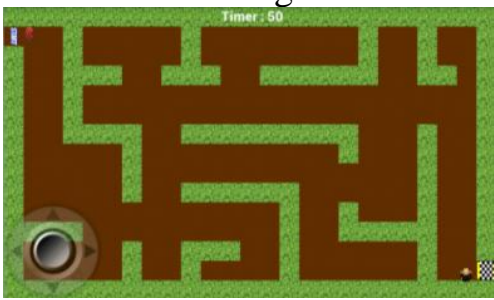

Gambar 4.9. Antarmuka halaman permainan level sedang3 


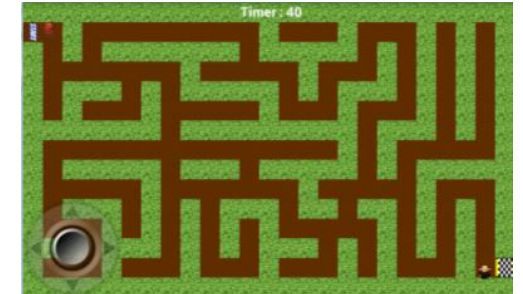

Gambar 4.10. Antarmuka halaman permainan level sulit1

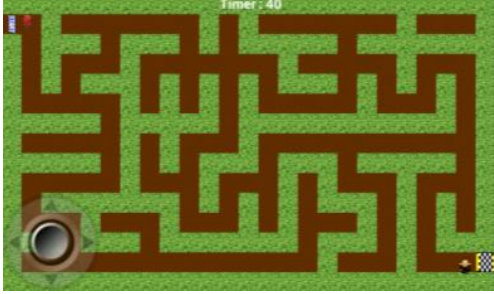

Gambar 4.11. Antarmuka halaman permainan level sulit2

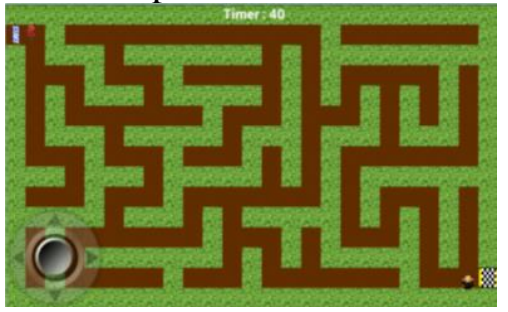

Gambar 4.12. Antarmuka

halaman permainan level sulit3

\section{Desain}

\section{Informasi}

Pada halaman Informasi ini menampilkan button yang menuju halaman-halaman tertentu, seperti pada gambar 4.13. berikut :

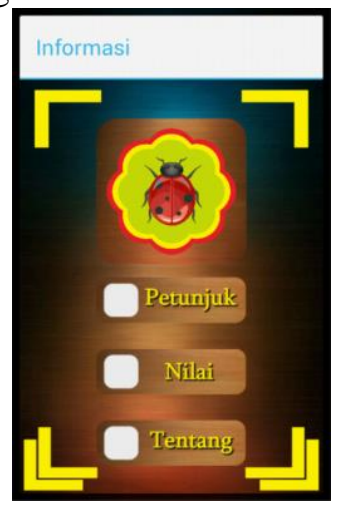

Gambar 4.13. Desain

Antarmuka Informasi

\section{Desain Antarmuka Petunjuk}

Pada halaman informasi petunjuk ini menampilkan informasi berupa cara dan aturan permainan, seperti pada gambar 4.5.

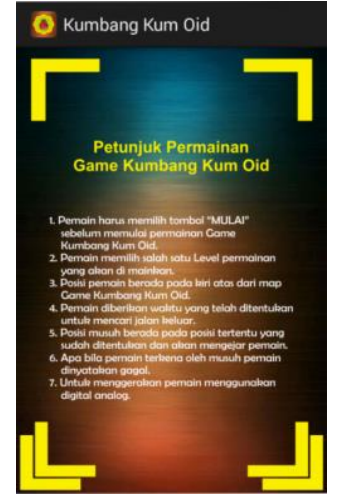

Gambar 4.14. Desain Antarmuka Petunjuk

\section{Desain Antarmuka Nilai}

Pada halaman informasi nilai ini menampilkan informasi berupa nilai dari hasil permainan game Kumbang Kum Oid, seperti pada gambar 4.15.

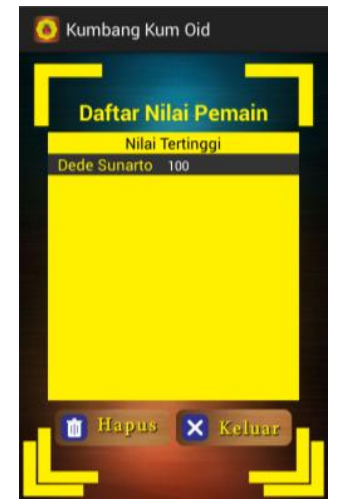

Gambar 4.15. Desain

Antarmuka Nilai

\section{Desain Antarmuka Tentang}

Pada halaman tentang ini menampilkan informasi tentang pembuat aplikasi game Kumbang Kum Oid seperti pada gambar 4.16 .

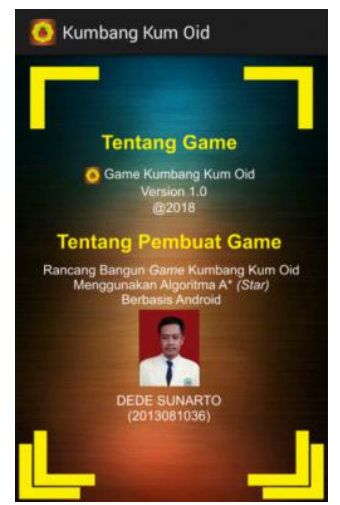

Gambar 4.16. Desain

Antarmuka Tentang 


\section{PENUTUP}

\subsection{Kesimpulan}

Kesimpulan yang didapatkan dari pembuatan permainan Game Kumbang Kum Oid adalah sebagai berikut.

1. Permainan game Kumbang Kum Oid terdiri dari 3 level yang memiliki kesulitan yang berbeda-beda sehingga disetiap levelnya pemain merasa tertantang dengan arena permainanya.

2. Dalam permainan game Kumbang Kum Oid terdapat rintangan berupa dinding, musuh yang akan mengejar pemain dan terdapat juga penilaian berupa lama waktu untuk mencapai jalan keluar.

3. Rancangan permainan pada game Kumbang Kum Oid 2D ini menggunakan Eclipse Mars AndEngine yang berbasis open source.

4. Game Kumbang Kum Oid ini dirancang bukan hanya untuk menyegarkan otak saja, tapi pembuat berupaya agar dapat melatih ketenangan, ketelitian dan kecepatan.

5. Permainan Game Kumbang Kum Oid menerapkan Algoritma A* (Star) pada musuh untuk mencari jalur tercepat.

\subsection{Saran}

Berdasarkan hasil dari game ini, maka saran untuk pengembangan aplikasi lebih lanjut adalah sebagai berikut.

1. Permainan game Kumbang Kum Oid ini bisa dikembangkan kembali dalam hal sisi grafik menjadi game 3D.

2. Belum tersedianya game Kumbang Kum Oid untuk pengguna app store.

\section{DAFTAR PUSTAKA}

Anggra. (2008). Memahami Teknik Dasar Pembuatan Game Berbasis Flash. Yogyakarta: Gava Media.

Al-Bahra. (2005). Analisis dan Desain Sistem Informasi. Yogyakarta: Graha Ilmu.

Budi Laksono, B. (2016). Aplikasi Game Labirin 2d Dengan Kecerdasan Buatan Yang Dapat Menghitung Jarak Pandang. Skripsi. Jurusan Teknik Informatika. Universitas Mercu Buana. Jakarta Barat.

Henry, S. (2005). Panduan Praktis Membuat Game 3D. Yogyakarta: Graha ilmu

Indrajani. (2011). Perancangan Basis Data dalam All in 1. Jakarta: PT. Elex Media Komputindo

Jogiyanto, H,M. (2001). Analisis Perancangan Sistem Informasi. Yogyakarta: Andi Offset.

Jogiyanto, H,M. (2005). Analisis dan Desain Sistem Informasi: Pendekatan Terstruktur Teori dan Praktek Aplikasi Bisnis. Yogyakarta: Andi

Krismiaji, (2005). Sistem Informasi Akutansi, Edisi Kedua. Akademi Manajemen, Yogyakarta.

Lewis, R,R. (2009). Understanding Pupil Behavior: Classroom Management Techniques for Teachers. New York: 270 Madison Avenue.

Munir, R. (2011). Algoritma dan Pemogaman. Bandung: Informatika. 
$>$ Nugroho, A. (2005). Analisis dan Perancangan Sistem Informasi dengan Metodologi Berotientasi Objek. Bandung: Informatika.

Pamungkas, A. (2014). Penerapan Algoritma $A^{*}$ (A Star) pada Game Edukasi The Maze Island Berbasis Android. Skripsi. Jurusan Teknik Informatika. STIMIK GI MDP. Palembang.

Pressman, Ph.D dan Roger, S. (2010). Pendekatan Praktisi Rekayasa Perangkat Lunak. Edisi 7 Yogyakarta: Andi

Pressman, Ph.D dan Roger, S. (2002). Rekayasa Perangkat Lunak Pendekatan Praktisi. Yogyakarta: Andi

Rosa, AS dan Shalahuddin, M. (2015). Rekayasa Perangkat Lunak. Bandung: Informatika.
Safaat, H,N. (2012) (Edisi Revisi). Pemograman Aplikasi Mobile Smartphone dan Tablet PC Berbasis Android. Bandung: Informatika.

Said, Fairuz, El. (2010). Sistem Basis Data-Entity Relatonship (ERD). http://fairuzelsaid.wordpress.com/20 10/03/16/sistem-basisdataentityrelationship-diagram-erd/. Diakses tanggal 4 Mei 2017.

Sutabri, T. (2005) (Edisi I). Sistem Informasi Manajemen. Yogyakarta: Andi.

Tridhonanto, Al. (2011). Optimalkan Potensi Anak Dengan Game. Jakarta: PT. Elex Media Komputindo 